DOI: 10.46340/ephd.2020.6.4.4

Dmytro Korzun

ORCID ID: https://orcid.org/0000-0002-5382-0438

National Scientific Agricultural Library of the National Academy

of Agrarian Sciences of Ukraine, Kyiv

\title{
THE REPRESSIVE POLICY OF THE RUSSIAN EMPIRE AUTHORITIES TOWARDS THE AGRONOMIST- INNOVATOR, I.YE. OVSINSKY (1856-1910)
}

\author{
Дмитро Корзун \\ Національна наукова сільськогосподарська бібліотека Національної аграрної \\ академії наук України, Київ

\section{РЕПРЕСИВНА ПОЛІТИКА ВЛАДИ РОСІЙСЬКОЇ ІМПЕРІЇ ЩОДО АГРОНОМА-НОВАТОРА, І.Є. ОВСІНСЬКОГО (1856-1910)}

\begin{abstract}
It is established that Ivan Yevhenovych Ovsinsky (1856-1910), known today as a scientific innovator, founder of organic and plowless farming, author of the world-famous book «New farming system» (1899) was persecuted by the authorities of the Russian Empire because of his Polish origin. It is determined that as a result of falsified criminal cases I.Ye. Ovsinsky was twicely imprisoned in the Podolsk province facilities (1874-1875 and 1887-1888) and was in exile in the Arkhangelsk province (1888-1893). He was found to have been under constant covert police surveillance since 1875. It is proved that the status of "politically unreliable person" negatively affected the further life and creative destiny of I.Ye. Ovsinsky, and leaded to the partial ban on scientific and journalistic activities, the prejudice of the professional scientific community, the refusal to cooperate with local governments.
\end{abstract}

Keywords: I.Ye. Ovsinski, imprisonment, exile, Poles, Podillia, the Russian Empire, repression, organic farming.

Постать Івана Євгеновича Овсінського (1856-1910) сьогодні відома серед аграрного співтовариства, зокрема тих, хто цікавиться історію зародження та становлення наукових основ органічного землеробства. Адже, у своїй праці «Нова система землеробства», яка вийшла друком наприкінці XIX ст. він виклав свою концепцію ведення самовідновлюваного землеробства, яка відповідала принципам раціонального використання природніх ресурсів при мінімальному впливі на рослину та грунт. Однак, попри значний розголос серед тогочасної наукової та виробничої громадськості його ідей, «система Овсінського» була дискредитована, тим самим, відкинувши ідею застосування екологічних основ ведення землеробства на довгі десятиріччя.

Розглядаючи причини несприйняття сучасниками цієї авторської системи, особливо у галузевому науковому середовищі, припускаємо, що за суто теоретичними дебатами могли стояти й інші мотиви відторгнення дослідника та його ідей. Зокрема, статус «політично неблагонадійного», який отримав I.Є. Овсінський, приймаючи участь у польському національно-визвольному русі, вплинув на його імідж серед державних чиновників Російської імперії. До їх числа в країні зараховувався професорсько-викладацький склад навчальних закладів, які представляли тогочасну офіційну наукову спільноту країни. 3 огляду на це постає наукове питання дослідити історію репресивної політики щодо І.С. Овсінського, що дозволить не лише грунтовніше вивчити біографію новатора, але зрозуміти механізми впливу та контролю владних органів за науковою та освітньою сферами в Російській імперії.

Вивчення життєвих віх I.Є. Овсінського вперше зацікавила вчених саме в контексті його участі у політичному житті Російської імперії. Вперше інформація біографічного змісту про нього була вміщена у багатотомному біо-бібліографічному словнику «Діячі революційного руху в Росії: 
від попередників декабристів до падіння царизму». Ця праця вийшла друком у 1927-1934 pp. видавництва Всесоюзного товариства політичних каторжан і засланців-поселенців під редакцією колегії із членів товариства - І.Д. Віленського-Сібірякова, Ф.Я. Кона, О.О. Шилова, Б.П. Козьміна, B.I. Невського та інших. Це видання важливе тим, що крім коротких біографічних відомостей про учасників революційного руху (загальна кількість статей - 17 809), укладачі вказали найголовніші джерела для їх вивчення. Цікавим $є$ той факт, що упорядники свідомо упускали оціночні судження щодо внеску та участі персоналії у суспільно-політичному русі, що було вкрай новаторським, зважаючи на час виходу цього видання. Словник було сформовано за хронологічним принципом, тому стаття про I.Є. Овсінського вміщена у 2 томі, присвяченому 70-м рокам XIX ст ${ }^{1}$. Варто відмітити, що саме у цьому виданні було вміщено фотографію діяча, яка по суті є єдиним портретом новатора.

Не зважаючи на досить активну увагу науковців, як радянських, так і польських, щодо дослідження польського політичного руху XIX ст., дослідження участі у ньому I.С. Овсінського залишилась поза увагою вчених. Ця персоналія стала цікавити дослідників з 60-х років XX століття лише в контексті відродження уваги до так званого полезахисного землеробства, яке пропагували у своїх роботах аграрії Т.С. Мальцев та О.І. Бараєв і основи якого висвітлював у своїх працях новатор $^{2} .3$ цього часу починається поступове повернення зацікавленості до творчої спадщини новатора, зокрема до його головної праці «Нова система землеробства». Однак питанню його суспільно-політичної діяльності увага не приверталась ${ }^{3}$. Сучасних вітчизняних дослідників постать I.Є. Овсінського цікавить в першу чергу щодо його внеску до становлення наукових поглядів щодо безплужного землеробства, організації сільськогосподарської дослідної справи. Тому, аналізуючи його публіцистичну діяльність, участь у сільськогосподарських громадських об'єднаннях, з'їздах господарів, взаємодії із місцевими земськими органами, дослідницький інтерес звернено лише щодо акцентуації I.Є. Овсінського як розбудовника вітчизняного аграрного дослідництва, де основні біографічні дані фактично повторюють інформацію вміщену на сторінках уже згаданого біобібліографічного словника $1931 \mathrm{p}^{4}$. Тому постає наукове завдання детальніше дослідити участь I.Є. Овсінського у суспільно-політичному житті Російської імперії, зокрема, через його участь у польському національно-визвольному русі XIX ст. та проаналізувати репресивну політику щодо цієї постаті в межах Російської імперії.

Іван Свгенович Овсінський походив із шляхетської родини землевласника Летичівського повіту Подільської губернії. Родинним маєтком було село Кальня Деражня, яке розташовувалось у 7 верстах від містечка Деражня, що було осередком польської та єврейської спільноти ${ }^{5}$. Роки дитинства новатора співпали із впровадженням селянської реформи 1861 р. та викупними операціями селянства для одержання землі, в наслідок чого маєток Овсінських значно скоротився 6 . Невелике господарство не приносило бажаних прибутків, а, отже, вимагало від власників запровадження інтенсивних методів господарювання, залучення фахівців для ефективного ведення родинної справи. Такі сподівання покладались на Івана Євгеновича, який успішно закінчив

\footnotetext{
${ }^{1}$ Виленский-Сибиряков, В., Кон, Ф., Шилов, А. и др. (ред.) (1931). Деятели революичонного движения в России : Био-библиографический словарь : От предшественников декабристов до падения ияаризма (1927-1934). Москва: Всесоюз. о-во полит. каторжан и ссыльно-поселенцев, 2, 3, 1070-1071.

2 Мальцев, Т. С. (1955). Вопросы земледелия: сборник статей и выступлений. Москва : Сельхозгиз. 432; Бараев, А. И. (1976). О научных основах земледелия в степных. Вестник сельскохозяйственной науки, $4,22-35$. ${ }^{3}$ Новиков, Ю. Ф., Истрати, А. К. (1983). Эволюция техники земледелия и проблема эрозии. Кишинев: Штиинца, 210; Пономарев, В. П. (1980). Система обработки почвы И. Е. Овсинского. Земледелие, 2, 58-59; Пономарев, В. П. (1981). Агрономическая наука Бессарабии в 1812-1917 г2. Кишинев : Штиинца, 95; Моргун, Ф. Т., Шикула, Н. К. (1988). Почвозащитное земледелие. Киев: Урожай, 256.

${ }^{4}$ Корзун, О. В. (2011). Становлення та розвиток сільськогосподарської дослідної справи на Поділлі (кінець ХІХпочаток XX ст.) Київ, 252; Вергунов, В. А. (2018). Овсінський Іван Євгенович. Історія сільськогосподарської дослідної справи в Украӥні. У 3 ч. Творці та розбудовники (біографічні нариси). Київ : Аграр. наука, 1, 390-394.; Орехівський, В. Д. (2017). Внесок І. С. Овсінського (1856-1909) установлення органічного землеробства на українських землях. Історія науки і біографістика <www.inb.dnsgb.com.ua/2017-3/10.pdf> (2020, листопад, 12); Самородов, В., Поспелов, С. (2011). Пространство и время Ивана Овсинского. Зерно. Журнал сучасного агропромисловия <www.zerno-ua.com/journals/2011/noyabr-2011-god/prostranstvo-i-vremya-ivana-ovsinskogo/> (2020, листопад, 12).

${ }^{5}$ Słownik geograficzny Królestwa Polskiego (1882). Kalna-Derażnia. Warszawa: Wieku, III, 702.

${ }^{6}$ Российский государственный исторический архив. Ф. 577. On. 29. Д. 965, 966.
} 
Кам'янець-Подільську гімназію та вступив до Новоросійського університету. Однак, юнак вихований на традиціях польських романтиків волів вивчати літературу, історію та філософію. Будучи студентом, він активно цікавився народницькою літературою, яка у тодішньої влади носила статус забороненої для прочитання. Вже у 1874 р. він разом із Самуїлом Музиченко ${ }^{1}$ та Станіславом Маркевичем $^{2}$ був затриманий за зберігання (книги «Вперед») та розповсюдження незаконної літератури. Поки тривало слідство I.Є. Овсінський утримувався у Летичівському тюремному замку з 10 жовтня 1874 р по 12 лютого 1875 p. I лише 11(27) вересня 1875 р. було винесено вирок тюремне ув'язнення на 4 місяці. Не отримавши офіційного диплому про освіту, судом не було накладено офіційних обмежень на заняття тою чи іншою діяльністю на противагу його побратимів. Так, негласну заборону на викладання роботи отримав С. Музиченко, коли з грудня $1877 \mathrm{p}$. по міністерству народної просвіти було видано розпорядження щодо недопущення його до педагогічної роботи ${ }^{3}$.

Подальша офіційна діяльність Івана Євгеновича була пов'язана із посередництвом у продажу маєтків та початком роботи в якості агронома у господарствах подільських землевласників. Зокрема, тоді ж він працює управителем маєтку Д.И. Матусевича в с. Гетьманівка Балтского повіту. Однак, протягом 12 років він знаходився під постійним негласним наглядом поліції, яка слідкувала за його частими закордонними відрядженнями, здійснюючи обшуки його речей при кожному перетині кордону та шукаючи привід для ув'язнення.

Така можливість випала 30 травня 1870 р. в м. Гусятині штабс ротмістру Окремого корпусу жандармів Устінову, який здійснюючи огляд речей I.С. Овсінського, що виїжджав через Кам'янецьПодільський закордон, знайшов «гальванічні знімки» з медалей, викарбованих на честь польського повстання 1863-1864 pр. та значну кількість рукописів польською мовою. Як зазначалось у документі, обшук речей І.Є. Овсінського було здійснено «у зв’язку із наявними вже відомостями про його сумнівну політичну благонадійність» ${ }^{4}$. 3 метою детального ознайомлення із документами, їх було у I.Є. Овсінського вилучено та відправлено для розгляду до начальника Подільського Губернського жандармського управління, а його самого ув'язнено в Кам'янецькому тюремному замку. Вже 12 червня 1887 р. було винесено вирок, де ув'язненого звинувачували у державній зраді та протиправних дії щодо верховної влади згідно статтею 251 «Уложения о наказаниях», що діяло в редакції 1885 р. Перший абзац вказаної статті передбачав позбавлення усього майна та заслання на каторжні роботи від 8 до 10 років винних у складанні та поширенні письмових чи друкованих об'яв, творів чи зображень, які мали на меті збудити до бунту чи іншій явній непокорі верховній владі 5

Доповідаючи прокурору Кам'янець-Подільської окружного суду 14 червня 1887 р. товариш прокурора Ченикаєв, наголошував, що «згідно відомостей, отриманих негласним методом», було відомо, що I.Є. Овсінський підтримував постійні відносини із певними особами закордоном, одержував зі Львова контрабандою літературу забороненого змісту. Вся поведінка підозрюваного теж викликала занепокоєння у влади, адже, проводячи посередницьку діяльність із продажу маєтків та лісів, він часто подорожував Подільською губернією, неодноразово бував закордоном, мав там знайомства із «політично неблагонадійними» особами та, крім того, був позаштатним співробітником деяких іноземних газет. В ході слідства з'ясувалось, що у серед рукописів були вірші, за підписом «A.M. Rolicz», авторство яких приписували затриманому, адже такий самий псевдонім було виявлено i на його візитівці. Аналізуючи зміст рукописів, зазначалось, що усі тексти були «явно тенденційного спрямування» щодо оскарження недоторканності прав верховної влади над краєм Поділля. Зокрема, в цьому аспекті згадуються вірші «Piesn bojowa» («Бойова пісня») та «Mysleli, Mysleli» («Думали, думали»), а твір «Wciągn naczego porazbiorawego zycia...» («Зрозумійте, чому життя після розділу...») на думку владної особи містив прямі заклики до непокори верховній владі. В зв'язку із викладеними матеріалами, проти I.Є. Овсінського було розпочато кримінальну справу за статтями 251 ч. 3 та 252 ч. 3 «Уложения о наказаниях», а підозрюваного продовжували утримувати у в'язниці до виплати ним

\footnotetext{
${ }^{1}$ Виленский-Сибиряков, В., Кон, Ф., Шилов, А. и др. (ред.) (1931). Деятели революиионного движения в России : Био-библиографический словарь : От предшественников декабристов до падения ияаризма (1927-1934). Москва: Всесоюз. о-во полит. каторжан и ссыльно-поселенцев, 2, 3, 980-981.

2 Там само, 882.

3 Там само, 981 .

4 Державний архів Хмельницької області. Ф. 281. Оn. 1. Спр. 1864. Арк. 3.

5 Таганцев, Н. С. (1886). Уложение о наказаниях уголовных и исправительных 1885 года. Санкт-Петербург: тип. М. Стасюлевича, 174-175.
} 
залогової суми у розмірі 3 тис. руб. ${ }^{1}$ Так, ст. 251 ч. 3 передбачала покарання у вигляді утримання у в'язниці від 1 року 4 місяців до 2 р. 8 місяців із позбавленням певних прав за складання творів чи зображень, метою яких $є$ спонукання до бунту проти діючої верховної влади, навіть не маючі наміру їх поширювати, що кваліфікувалось як приготування та початок замаху². А у статті 252 ч. 3 вказувалось, що винним у складанні творів подібного змісту, які не мають намірів у їх поширенні інкримінується злочинний умисел та карається ув'язненням від 8 місяців до 1 року 4 місяців ${ }^{3}$.

Крім того, було вирішено продовжувати справу згідно статтею 1035 «Уставу уголовного судопроизводства», яка регламентувала діяльність ведення справ судовою палатою. Так, зазначалось, що про будь-які протиправні дії, які мають ознаки державного злочину має бути повідомлено прокурору судової палати чи товаришу прокурора ${ }^{4}$. Тому всі дані щодо ведення цієї справи доповідались прокурору Одеської судової палати ${ }^{5}$ Саме він у своєму висновку від 20 червня цього ж року скасував рішення прокурора Кам'янець-Подільського окружного суду щодо звільнення I.Є. Овсінського під заставу, а наполягав «на безумовному утриманню під вартою» ${ }^{6}$

В ході слідства було встановлено, що більшість кореспонденції вилученої в І.Є Овсінського адресувалась адресату «Ignacy». Однак, жодних відомостей, що б дозволило ідентифікувати цю особу Управління Південно-Західних залізничних шляхів, Київське, Кам'янець-Подільське, міське Одеське жандармські управління не надали ${ }^{7}$. Аналізуючи документи справи Овсінського, чітко простежується, що особливих доказів його злочинної діяльності у владних органів не було. Про це свідчить ще й лист прокурора Одеської судової палати до прокурора Кам'янець-Подільського окружного суду від 12 жовтня $1887 \mathrm{p}^{8}$. Зокрема, автор документу наголошує, що підстави для обвинувачення Овсінського могли базуватись лише на змісті вилучених у нього листів та заміток. Єдиною особою, яка читала ці рукописи був штабс ротмістр Устінов, однак його рапорт не містив детального аналізу текстів. Тому на товариша прокурора Ченикаєва були покладені обов'язки доповнити дані шляхом продовження дізнання, але нових даних по справі виявлено не було.

Розгляд справи Овсінського закінчився 26 березня 1888 р, коли згідно повелінню діючого імператора Олександра III, ув'язненого було заслано на проживання під нагляд поліції в Архангельську губернію строком на 5 років ${ }^{9}$. Пізніше, 5 травня цього ж року І.Є. Овсінського було переведено у Холмогори, а потім у Шенкурськ Архангельської губернії. У той час губернія охоплювала більшу частину Європейської Півночі Російської імперії, включаючи частину території сучасної Карелії, республіки Комі, а також Архангельської та Мурманської областей. Суворі кліматичні умови, низька щільність населення при порівняно незначному віддаленні від центрів країни, необхідність освоєння цих територій обумовили обрання цього регіону в якості місця масових заслань «неугодних уряду осіб».

Згідно із російським законодавством висилка під нагляд поліції вважалась набагато м'якшим покаранням, ніж ув'язнення в арестантські роти чи каторжні роботи і застосовувалася переважно щодо представників привілейованих станів. Однак часто умови життя арештантів були кращі, ніж у піднаглядних, адже їм доводилось самостійно піклуватись про своє харчування, одяг, житло та лікування. Для польської національної спільноти Російської імперії цей край став своєрідним центром національної репресованої опозиції. Зокрема, саме сюди було вислано учасників Листопадового повстання 1830-1831 pp. (600 осіб) та Січневого повстання 1863-1864 pp. (974 особи) ${ }^{10}$ Згідно із висновками вчених, які досліджували історію польських засланців у цьому краї відомо, що практично усі заслані поляки мешкали у малонаселених повітових містечках, де утворювали досить великі колонії та вели замкнутий стиль життя, їх контакти із місцевим населенням були слабкі та обмежувались

\footnotetext{
${ }^{1}$ Державний архів Хмельницької області. Ф. 281. On. 1. Сnp. 1864. Арк. 6-6 зв.

2 Таганцев, Н. С. (1886). Уложение о наказаниях уголовных и исправительных 1885 года. Санкт-Петербург: тип. М. Стасюлевича, 256.

${ }^{3}$ Там само, 257.

${ }^{4}$ Устав уголовного судопроизводства. (1867). Судебные уставы 20 ноября 1864 года : с изложением рассуждений, на коих они основаны. Санкт-Петербург : в типографии 2 отделения Собственной Е. И. В. Канцелярии, 2, 393.

${ }^{5}$ Державний архів Хмельницької області. Ф. 281. On. 1. Сnp. 1864. Арк. 7-7 зв.

${ }^{6}$ Державний архів Хмельницької області. Ф. 281. On. 1. Сnp. 1864. Арк. 8-8 зв.

7 Державний архів Хмельницької області. Ф. 281. On. 1. Сnp. 1864. Арк.10-10 зв.

8 Державний архів Хмельницької області. Ф. 281. On. 1. Сnp. 1864. Арк. 11-11 зв.

9 Державний архів Хмельницької області. Ф. 281. On. 1. Сnp. 1864. Арк. 17-17 зв.

${ }^{10}$ Кононова, Л. П. (2004). Ссылка участников польского восстания 1863-1864 годов (по материалам Архангельской губернии). Архангельск: Поморский госуниверситет, 64.
} 
виключно відносинами побутового та майнового характеру. Особливістю перебування у цьому краї для засланців становив суворий північний клімат, що утруднював адаптацію та ставав причиною багатьох хвороб. Для засланців це місце асоціювалось із в'язницею, тому вони зовсім не прагнули до вкорінення чи асиміляції, живучи замкненими общинами, уникаючи контактів як із місцевим населенням, так i з політичними засланцями інших національностей. Ускладнювало контакти засланих сюди поляків із місцевим населенням ще його однорідність у національному відношенні, порівняно із іншими подібними місцями каторг та заслань, що функціонували у країні, зокрема, Сибіром та Поволжям. У цих регіонах, які у своєму складі мали значну строкатість як унаціональному, так і конфесійному відношенні, на собі відчуваючи усі утиски національної та конфесійної політики царського режиму, польські засланці частіше зустрічали співчуття та швидше налагоджувалась комунікація.

Слід наголосити також i на цивілізаційний вплив, який здійснили польські поселенці на розвиток Архангельської Півночі. Маючи значно високий, порівняно із місцевим населенням, рівень освіти, а також гострий дефіцит кваліфікованих кадрів у віддалених регіонах країни, поселенці часто були затребувані місцевими чиновниками та брали активну участь у різних галузях життя краю. Не зважаючи на заборону, вони викладали місцевим мешканцям іноземні мови, музику, танці, займались статистичними описами губернії, науковою та публіцистичною, комерційною та навіть законотворчою діяльністю. Однак в Архангельській губернії лише одиниці поселенців та засланців були задіяні у місцевому громадському житті. Тому після відбування покарання майже усі із них залишали цю місцевість.

Достеменно відомо, що І.Є. Овсінський продовжував цікавитись економічним та громадським життям правобережних губерній Російської імперії, про що свідчить його активна участь у Першому Київському обласному сільськогосподарському з'їзді, який проходив 10-20 листопада 1890 р., організованому найвпливовішою громадською організацією аграрного спрямування, Київським товариством сільського господарства та сільськогосподарської промисловості (далі - КТСГ). З'їзд був скликаний для напрацювання системи заходів щодо здешевлення виробництва зернової продукції для правобережних губерній ${ }^{1}$. Перебуваючи ще ум. Шенкурськ Архангельської губернії, I.Є. Овсінський надіслав до оргкомітету з'їзду свою доповідь, яка була присвячена заходам щодо упорядкування сільськогосподарських господарств. Саме на цьому зібранні I.Є. Овсінський презентував концепцію перетворень в організації аграрного виробництва та систему агротехнічних прийомів ведення землеробства ${ }^{2}$. В майбутньому основні положення доповіді були розвинені автором у його монографіях: «Організм економічний» $(1897)^{3}$ та «Нова система землеробства» $(1899)^{4}$.

Аналіз подальших життєвих та творчих віх І.С. Овсінського свідчить про те, що після відбування заслання він до кінця свого життя знаходився під особливим негласним контролем з боку поліційних органів Російської імперії. Зокрема, про це свідчать рапорти Іркутського міського поліційного управління, які здійснювали за ним нагляд восени $1893 \mathrm{p}^{5}$.

Статус «політично неблагонадійного» впливав і на його науково-публіцистичну діяльність. Після публічного оприлюднення основних положень своєї авторської концепції щодо ведення землеробства серед учасників вказаного з'їзду, ідеї І.С. Овсінського набули не аби-якої популярності. Це спонукало КТСГ до організації обговорення «Нової системи землеробства» на своїх засіданнях та на сторінках друкованого органу - журналу «Земледелие». Аналіз статей журналу за 1899-1903 pp. дає підстави стверджувати, що редакційна політики цього видання носила завідомо упереджений характер щодо автора системи та його ідей. Так, поряд із анонсами щодо публічних виступів I.Є. Овсінського розміщувались статті авторів під псевдонімами, які налаштовували читачів на негативне сприйняття концепції новатора, критикуючи будь-які його докази ${ }^{6}$ Це було лише початком цькування дослідника, що завершилось у наступних роках невиправданою дискредитацією його методики обробітку грунту.

\footnotetext{
${ }^{1}$ Рева, И. М. (ред.) (1890). Труды Первого Киевского областного сельскохозяйственного съезда. Киев : Тип. Петра Барского, 10.

2 Рева, И. М. (ред.) (1890). Труды Первого Киевского областного сельскохозяйственного съезда.

Киев : Тип. Петра Барского, 161-170.; Центральний державний історичний архів України, м. Київ. Ф. 731.

On. 1. Спр. 3. Арк. 10-10 (зв).

${ }^{3}$ Owsinski, J. (1897). Organizm ekonomiczny. Warszawa: Drukim Władysława Szulca, 14.

${ }^{4}$ Овсинский, И. (1899). Новая система земледелия. Киев : тип. С. В. Кульженко, 174.

${ }^{5}$ Государственный архив Иркутской области. Ф. 91. Оп. 1. Т. 2. Д. 2006.

6 Земледелец (1899). Отголоски. Земледелие, 13, 194-196.; Сельский счетовод (1899). Маленькая цифровая проверка рекламы (письмо в редакцию). Земледелие, 14, 205-207.
} 
Ще більш трагічна доля спіткала його інші твори, присвячені економічним питанням, проблемам ведення садівничої справи тощо. Офіційна цензура так і не дала дозволу на переклад російською його творів. Зокрема, заборону на перевидання польською та переклад на російську отримала його праця «Organizm ekonomiczny»» ${ }^{1}$. А інші твори - «Miejsce na sad» (1897) («Mісце під сад») $)^{2}$, «Nowy system sadownictwa» (1906) («Нова система садівництва») ${ }^{3},-$ були надруковані польською мовою, коштом автора та мізерними накладами. Тому сьогодні ці видання $є$ незнаними серед фахового наукового середовища, зберігаються лише у бібліотеці Варшавського університету і становлять бібліографічну рідкість.

Відмова на рівні влади просувати ідеї І.С. Овсінського через їх опублікування, настрої серед тогочасного аграрного наукового співтовариства, які опозиційно були налаштовані щодо нього та його системи землеробства, що базувались мінімальному обробітку грунту і фактичній відмові від використання плугу, не дозволила новатору відстояти свою концепцію й отримати для неї статус офіційно визнаної. Усі свої експерименти він проводив лише в межах свого господарства, де заснував Кально-Деражнянську помологічну станцію. Протягом 10 років він успішно займався дослідництвом уцій сфері, допомагаючи місцевим господарям у поширенні селекційного матеріалу, консультуванні щодо ведення плодово-ягідної справи. Розуміючи власну обмеженість у доступі до інформаційних, фінансових, експертних ресурсів, через свій особливий статус як серед владних структур, так і серед наукової громадськості, дослідник у 1909 р. ініціює клопотання перед подільським земством про передачу його дослідної установи на баланс органів місцевого самоврядування та пропонує відкрити на базі станції школу садівництва із дослідним садом. Однак, отримавши негласну вказівку від міністерських установ про відхилення жодних ініціатив від цієї персони, подільське земство відмовило I.Є. Овсінському в його проханні, мотивуючи, що станція мала характер приватного господарства, функціонувала із промисловою метою ${ }^{4}$. На жаль, подільська громада не скористалась напрацюваннями I.С. Овсінського в галузі садівництва для потреб місцевого населення. А відкриття науково-дослідної установи садівничого напрямку в подільському регіоні затяглось аж до кінця 60 -х років XX ст. ${ }^{5}$

Таким чином, I.Є. Овсінський, зазнавши переслідувань з боку владних органів Російської імперії, був звинувачений у протиправних діях щодо верховної влади країни. Йому інкримінували зберігання та розповсюдження забороненої літератури народницького ухилу, створення польськомовних текстів, які піддавали сумніву законність прав діючої влади на території Східного Поділля. Статус «політично неблагонадійного», який він отримав після ув'язнення та заслання до Архангельської губернії, вплинула на його подальшу життєву та творчу долю.

\section{References:}

1. Vilenskii-Sibiriakov, V., Kon, F., Shilov, A.and others (ed.) (1931). Deiateli revoliutcionnogo dvizheniia v Rossii: Bio-bibliograficheskii slovar: Ot predshestvennikov dekabristov do padeniia tcarizma (1927-1934) [Figures of the revolutionary movement in Russia: Bio-bibliographic dictionary: From the predecessors of the Decembrists to the fall of tsarism (1927-1934)]. Moscow: Vsesoiuz. o-vo polit. katorzhan i ssylno-poselentcev, 2, 3, 1070-1071. [in Russian].

2. Maltcev, T. S. (1955). Voprosy zemledeliia: sbornik statei i vystuplenii [Agricultural issues: a collection of articles and speeches]. Moscow. [in Russian]

3. Baraev, A. I. (1976). O nauchnykh osnovakh zemledeliia v stepnykh rayonakh. [On the scientific foundations of agriculture in the steppe regions]. Vestnik selskokhoziaistvennoi nauki [Bulletin of Agricultural Science], 4, 22-35. [in Russian].

4. Novikov, Iu. F., Istrati, A. K. (1983). Evoliutciia tekhniki zemledeliia i problema erozii [The evolution of farming techniques and the problem of erosion]. Kishinev: Shtiintca. [in Russian].

5. Ponomarev, V. P. (1980). Sistema obrabotki pochvy I. E. Ovsinskogo. [Soil cultivation system of I. E. Ovsinsky]. Zemledelie. [Agriculture], 2, 58-59. [in Russian].

6. Ponomarev, V. P. (1981). Agronomicheskaia nauka Bessarabii v 1812-1917 gg. [Agronomic science of Bessarabia in 1812-1917]. Kishinev: Shtiintca. [in Russian].

\footnotetext{
${ }^{1}$ Российский государственный исторический архив.Ф. 776 On. 21 Ч. 1. Д. 435.

${ }^{2}$ Owsinski, J. (1897). Miejsce na sad. Warszawa: Drukarnia Artystyczna, 22.

${ }^{3}$ Owsinski, J. (1906). Nowy system sadownictwa. Kijow: Drukarnia R. Łubkowskiego, 51.

4 Державний архів Хмельницької області. Ф. 233. On. 1. Сnp. 310. С. 109-110.

${ }^{5}$ Корзун, О. В. (2011). Становлення та розвиток сільськогосподарської дослідної справи на Поділлі (кінець ХІХпочаток XX cm.). Київ: НААН, ДНСГБ, 139.
} 
7. Morgun, F. T., Shikula, N. K. (1988). Pochvozashchitnoe zemledelie [Conservation agriculture]. Kyiv: Urozhai. [in Russian].

8. Korzun, O. V. (2011). Stanovlennia ta rozvytok silskohospodarskoi doslidnoi spravy na Podilli (kinets XIXpochatok XX st.) [Formation and development of agricultural research in Podillya (late nineteenth - early twentieth century)]. Kyiv. [in Ukrainian].

9. Verhunov, V. A. (2018). Ovsinskyi Ivan Yevhenovych. [Ovsinsky Ivan Yevhenovych]. Istoriia silskohospodarskoi doslidnoi spravy v Ukraini. U 3 ch. [History of agricultural research in Ukraine. In 3 parts]. Kyiv: Ahrar. Nauka, 1. [in Ukrainian].

10. Orekhivskyi, V. D. (2017). Vnesok I. Ye. Ovsinskoho (1856-1909) u stanovlennia orhanichnoho zemlerobstva na ukrainskykh zemliakh. [I.Ye. Ovsinsky's contribution (1856-1909) to the formation of organic farming in the Ukrainian lands.] Istoriia nauky i biohrafistyka. [History of Science and Bioraphistics.]. <www.inb.dnsgb.com.ua/2017-3/10.pdf> (2020, November, 12). [in Ukrainian].

11. Samorodov, V., Pospelov, S. (2011). Prostranstvo i vremia Ivana Ovsinskogo [Space and time of Ivan Ovsinsky]. Zerno. Zhurnal suchasnoho ahropromyslovtsya [Grain. Journal of the modern agro-industrialist.]. <www.zerno-ua.com/journals/2011/noyabr-2011-god/prostranstvo-i-vremya-ivana-ovsinskogo> (2020, November, 12). [in Russian].

12. Słownik geograficzny Królestwa Polskiego (1882) [Geographical dictionary of the Kingdom of Poland (1882)]. Kalna-Derażnia [Kalna-Derazhnia]. Warszawa: Wieku, III, 702. [in Polish].

13. Rossiiskii gosudarstvennyi istoricheskii arkhiv. [Russian State Historical Archives.]. F. 577. Op. 29. D. 965 , 966. [in Russian]

14. Derzhavnyi arkhiv Khmelnytskoi oblasti. [State Archives of Khmelnytsky region.]. F. 281. Op. 1. Spr. 1864. [in Russian]

15. Tagantcev, N. S. (1886). Ulozhenie o nakazaniiakh ugolovnykh i ispravitelnykh 1885 goda [Code on penal and correctional punishments 1885]. Sankt-Peterburg: M. Stasiulevich, 174-175. [in Russian].

16. Ustav ugolovnogo sudoproizvodstva (1867). Sudebnye ustavy 20 noiabria 1864 goda: s izlozheniem rassuzhdenii, na koikh oni osnovany [Judicial Charters November 20, 1864: outlining the reasoning on which they are based: Part 2: Charter of Criminal Procedure. (1867)]. Sankt-Peterburg: v tipografii 2 otdeleniia Sobstvennoi E. I. V. Kantceliarii, 2, 393. [in Russian].

17. Kononova, L. P. (2004). Ssylka uchastnikov polskogo vosstaniia 1863-1864 godov (po materialam Arkhangelskoi gubernii). [Exile of the participants in the Polish uprising of 1863-1864 (based on materials from the Arkhangelsk region)]. Arkhangelsk: Pomorskii gosuniversitet. [in Russian].

18. Reva, I. M. (ed.) (1890). Trudy Pervogo Kievskogo oblastnogo selskokhoziaistvennogo sezda [Proceedings of the First Kiev Regional Agricultural Congress]. Kiev: Tip. Petra Barskogo. [in Russian].

19. Tsentralnyi derzhavnyi istorychnyi arkhiv Ukrainy, m. Kyiv. [Central State Historical Archive of Ukraine, Kyiv.]. F. 731. Op. 1. Spr. 3. [in Russian].

20. Owsinski, J. (1897). Organizm ekonomiczny. [Economic organism]. Warszawa: Drukim Władysława Szulca. [in Polish].

21. Ovsinskii, I. (1899). Novaia sistema zemledeliia [New farming system]. Kiev: S. V. Kulzhenko. [in Russian].

22. Gosudarstvennyi arkhiv Irkutskoi oblasti. [State Archives of the Irkutsk Region.]. F. 91. Op. 1. T. 2. D. 2006. [in Russian].

23. Zemledeletc (1899). Otgoloski. [Echoes]. Zemledelie. [Agriculture], 13, 194-196. [in Russian].

24. .Selskii schetovod. (1899). Malenkaia tcifrovaia proverka reklamy (pismo v redaktciiu). [Small digital ad check (letter to the editor)]. Zemledelie. [Agriculture], 14, 205-207. [in Russian].

25. Rossiiskii gosudarstvennyi istoricheskii arkhiv. [Russian State Historical Archive]. F. 776 Op. 21 CH. 1. D. 435. [in Russian].

26. Owsinski, J. (1897). Miejsce na sad. [Place for the orchard]. Warszawa: Drukarnia Artystyczna. [in Polish].

27. Owsinski, J. (1906). Nowy system sadownictwa. [New horticulture system]. Kyiv: Drukarnia R. Łubkowskiego. [in Polish].

28. Derzhavnyi arkhiv Khmelnytskoi oblasti [State Archives of Khmelnytsky region.]. F. 233. Op. 1. Spr. 310. [in Russian]. 